\title{
Inhibitory activity against $a$-amylase and $\alpha$-glucosidase by phenolic compounds of quinoa (Chenopodium quinoa Willd.) and cañihua (Chenopodium pallidicaule Aellen) from the Andean region of Peru
}

\author{
Jorge Coronado-Olano ${ }^{1,5}$, Ritva Repo-Carrasco-Valencia ${ }^{1}$, Oscar Reategui ${ }^{2}$, Emily Toscano ${ }^{3}$, Elisa Valdez ${ }^{4}$, \\ Mirko Zimic ${ }^{3}$, Ivan Best ${ }^{6, *}$
}

Jorge Coronado-Olano ${ }^{1,5}$, Ritva

Repo-Carrasco-Valencia' ${ }^{1}$, Oscar Reategui ${ }^{2}$, Emily Toscano ${ }^{3}$, Elisa Valdez4, Mirko Zimic ${ }^{3}$, Ivan Best ${ }^{6, *}$

${ }^{1}$ Facultad de Industrias Alimentarias, Universidad Nacional Agraria La Molina Lima, PERU.

${ }^{2}$ Carrera de Ingeniería Agroforestal, Universidad Científica del Sur, Lima, PERU. ${ }^{3}$ Laboratorio de Bioinformática y Biología Molecular, Laboratorios de Investigación y Desarrollo (LID), Universidad Peruana Cayetano Heredia, Lima, PERU.

${ }^{4}$ Universidad Nacional Federico Villarreal, Lima, PERU.

${ }^{5}$ Hersil S. A Laboratorios Industriales

Farmacéuticos, Lima, PERU.

${ }^{6}$ Unidad de Investigación en Nutrición, Salud, Alimentos Funcionales y Nutracéuticos,

Universidad San Ignacio de Loyola (UNUSANUSIL), Calle Toulon 310, 15024 Lima, PERU.

\section{Correspondence}

\section{Dr. Ivan Best}

Unidad de Investigación en Nutrición

Salud, Alimentos Funcionales y

Nutracéuticos, Universidad San Ignacio de

Loyola (UNUSAN-USIL), Calle Toulon 310,

15024 Lima, PERU.

E-mail: ibest@usil.edu.pe

History

- Submission Date: 15-02-2021;

- Review completed: 18-04-2021;

- Accepted Date: 26-04-2021.

DOI : 10.5530/pj.2021.13.115

Article Available online

http://www.phcogj.com/v13/i4

\section{Copyright}

(C) 2021 Phcogj.Com. This is an openaccess article distributed under the term of the Creative Commons Attribution 4.0 International license.

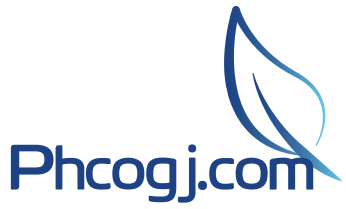

\section{ABSTRACT}

Background: Chenopodium quinoa Willd. and Chenopodium pallidicaule Aellen are grains from the Andean region of Peru, which in addition to having a high nutritional value, have health-promoting properties related to the prevention of chronic diseases such as diabetes. Objetive: The present study aimed to identify phenolic compounds associated with an inhibition of carbohydrate hydrolyzing enzymes associated with type 2 diabetes. Material and Methods: Two varieties of quinoa and two varieties of cañihua from the Puno Region in Peru, were evaluated. Total phenolics, total flavonoids, identification of phenolic compounds and antioxidant activity in vitro were measured by Folin-Ciocalteu assay, aluminum chloride colorimetric method, HPLC-DAD and DPPH radical scavenging assay, respectively. In vitro hypoglycemic activity was evaluated through the inhibition of the $\alpha$-amylase and $\alpha$-glucosidase enzymes. Results: Gallic acid, rutin and chlorogenic acid were identified by HPLC-DAD in the varieties of quinoa and cañihua. The latter showed significantly higher levels of chlorogenic acid compared to quinoa varieties $(p<0.05)$. Both Andean grains exhibited inhibition of key-enzymes linked to type 2 diabetes, presenting $I_{50}$ values of 7.99 to 34.05 and of 8.07 to $1158 \mu \mathrm{g} / \mathrm{mL}$ for $\alpha$-amylase and $\alpha$-glucosidase, respectively. Total phenolics, total flavonoids, DPPH radical scavenging assay, gallic acid and chlorogenic acid showed the greatest contribution to the inhibitory activity of the $\alpha$-glucosidase enzyme $(p<0.05)$. Conclusion: Our findings suggest that the phenolic compounds present in the varieties of quinoa and cañihua could modulate the inhibition of carbohydrate hydrolyzing enzymes associated with type 2 diabetes.

Key words: Andean grains, DPPH radical scavenging assay, HPLC-DAD, In vitro antidiabetic activity, Polyphenols.

\section{INTRODUCTION}

Quinoa (Chenopodium quinoa Willd.) and cañihua (Chenopodium pallidicaule Aellen) are nutritive grains cultivated in the highlands of Peru. These crops were used by pre-columbian cultures in South America for centuries, being very important to the Incas, along with corn and potatoes. The genetic variability of these grains is enormous because cultivars grow from sea level to highlands and from the cold climate of the highlands to subtropical conditions. They are generally called pseudocereals, as they are not members of the gramineae family, but produce seeds that can be ground and used as cereals. These grains do not contain gluten and can be consumed by people diagnosed with coeliac disease, it is also used in baby food. ${ }^{1}$ Due to its functional and biological properties, quinoa has been defined as "one of the grains of the XXI century". Besides its high content in proteins, lipids, fiber, vitamins and minerals and its excellent essential amino acids balance, it has been found that it contains numerous phytochemicals that include saponins, phytosterols, phytosteroids, phenolic compounds and bioactive peptides. These compounds may have beneficial effects on metabolic, cardiovascular and gastrointestinal health., ${ }^{2,3}$

The cañihua originates from the Andes region of southern Peru and Bolivia, being distributed in the highest semi-arid regions. The cañihua grain presents high protein content (15-19\%), as well as a significant proportion of sulfur amino acids and a balance of amino acids of optimum quality, rich in lysine, isoleucine and tryptophan. ${ }^{4,5}$

Bioactive compounds like phenolics and carotenoids found in vegetables, fruits and grains can have antioxidant and anti-inflammatory effects, which make them good candidates for the prevention of chronic diseases such as diabetes. ${ }^{6}$

In the Americas, diabetes cases are estimated to increase from 24 million in 2013 to 38.5 million in $2035 .^{7}$ In Peru, type 2 diabetes mellitus represents $97 \%$ of cases and appears more frequently after the age of $44^{8}$, with 2 new cases per 100 people per year. ${ }^{9}$ In recent years, some natural inhibitors of $\alpha$-amylase and $\alpha$-glucosidase have been identified in plants,

Cite this article: Coronado-Olano J, Repo-Carrasco-Valencia $R$, Reategui $O$, Toscano $E$, Valdez E, Zimic M, et al. Inhibitory Activity Against $\alpha$-amylase and $\alpha$-glucosidase by Phenolic Compounds of quinoa (Chenopodium quinoa Willd.) and Cañihua (Chenopodium pallidicaule Aellen) from the Andean Region of Peru. Pharmacog J. 2021;13(4): 896-901. 
which offer a good strategy to control postprandial hyperglycemia (a stage prior to the development of diabetes mellitus type 2) in a natural way without the side effects associated with conventional treatment such as abdominal distension, flatulence and diarrhea. ${ }^{10}$ The objective of the present study was to identify the phenolic compounds present in two varieties of quinoa and two varieties of cañihua from the Andean Region of Peru that could be related to the inhibition of carbohydrate hydrolyzing enzymes associated with type 2 diabetes.

\section{MATERIAL AND METHODS}

\section{Materials}

Certified seeds of two commercial varieties of quinoa (Chenopodium quinoa Willd.): "Salcedo INIA" (QSI) and "Negra Collana" (QNC) ${ }^{11}$ and two commercial varieties of cañihua (Chenopodium pallidicaule Aellen): "INIA 406-ILLPA" (CII) and "Cupi" (CCC) ${ }^{12,13}$ were provided by the ILLPA-Puno Agricultural Experiment Station, located at 2815 meters above sea level in the Paucarcolla District, Puno Region, Peru (Figure 1).

\section{Sample preparation}

To obtain a better extraction, the quinoa and cañihua grains were ground. Previously, only quinoa was scarified with $\mathrm{N}^{\circ} 210$ abrasive paper to remove saponin. Both grains were then individually ground (Rotor Beater Mill SR 300) with a $0.2 \mathrm{~mm}$ screen. To carry out subsequent measurements, an extract was prepared from the flour sample obtained from each sample, in a ratio $1: 7$ with $80 \%$ ethanol $(\mathrm{w} / \mathrm{v})$, with constant stirring in a water bath at a temperature of 50 ${ }^{\circ} \mathrm{C}$ for $2 \mathrm{~h}$. After incubation, the extract was filtered with Whatman paper $\mathrm{N}^{\circ} 2 .{ }^{14}$ The purification of bioactive compounds was carried out by solid-phase extraction (SPE) in columns ENVITM-18 (SigmaAldrich, USA). This column was conditioned with ethanol and acidified water ( $\mathrm{pH}$ 2). Subsequently, $60 \mathrm{~mL}$ of the sample was added, the column was washed with $40 \mathrm{~mL}$ of acidified water, and the elution was performed with $40 \mathrm{~mL}$ of ethanol acidified with $1 \%$ glacial acetic acid. Then, all the solvent was evaporated in vacuum at $40{ }^{\circ} \mathrm{C}$ for 2 h. The purified dry extract (PDE) was used to perform all the assays described below.

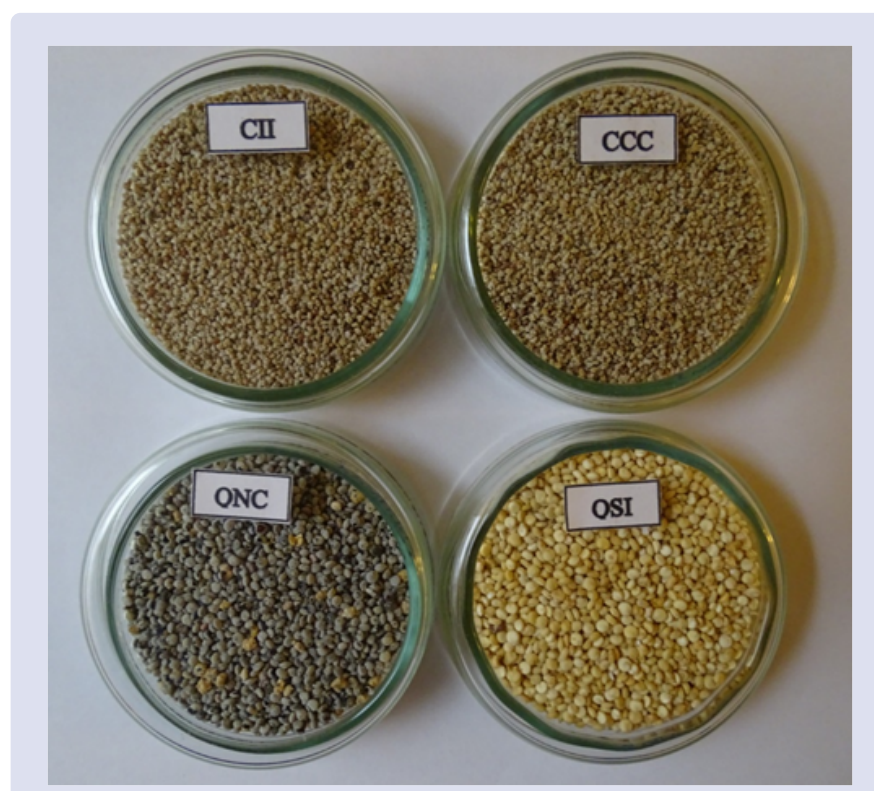

Figure 1: Cañihua ILLPA INIA (CII), Cañihua Cupi (CCC), Quinoa Negra Collana (QNC) and Quinoa Salcedo INIA (QSI).

\section{Total phenolic content}

Total phenolics were measured using the Folin-Ciocalteu method according to Herrera-Calderon et al. ${ }^{15}$, with minor modifications. To $0.1 \mathrm{~mL}$ of sample, $1 \mathrm{~mL}$ of $10 \%$ Folin-Ciocalteu reagent was added and it was left for $5 \mathrm{~min}$ at room temperature. Subsequently, $1 \mathrm{~mL}$ of $5 \% \mathrm{Na}_{2} \mathrm{CO}_{3}$ was added to the mixture, and it was incubated at $45^{\circ} \mathrm{C}$. The absorbance was measured after $30 \mathrm{~min}$ at $725 \mathrm{~nm}$. Total phenolic content was expressed in $\mathrm{mg}$ of gallic acid equivalent (GAE) per $\mathrm{g}$ of purified dry extract (mg GAE/g PDE).

\section{Total flavonoid content}

Total flavonoid content was determined using a modification of the method proposed by Wolfe et al. ${ }^{16}$ To $250 \mu \mathrm{L}$ of sample, $125 \mu \mathrm{L}$ of distilled water and $75 \mu \mathrm{L}$ of $5 \%$ sodium nitrite were added, this mixture was left for $5 \mathrm{~min}$, then $150 \mu \mathrm{L}$ of $10 \%$ aluminum chloride was added, allowing it to stand for $6 \mathrm{~min}$. Finally, $0.5 \mathrm{~mL}$ of $2 \mathrm{M} \mathrm{NaOH}$ and $275 \mu \mathrm{L}$ of distilled water were added. The absorbance was measured immediately at $510 \mathrm{~nm}$. Total flavonoid content was expressed in $\mathrm{mg}$ of catechin equivalent (CE) per g of purified dry extract (mg CE/g PDE).

\section{Antioxidant activity by DPPH radical scavenging assay}

In vitro antioxidant activity was evaluated by the DPPH radical scavenging assay according to Brand-Williams et al. ${ }^{17}$ At different sample concentrations $(10,20,50,75,100$ and $200 \mathrm{uL}), 1 \mathrm{~mL}$ of 0.1 $\mathrm{M}$ acetate buffer ( $\mathrm{pH} 6.0$ ), $1.5 \mathrm{~mL}$ of methanol and $0.5 \mathrm{~mL}$ of 0.1 $\mathrm{mM}$ DPPH were added, this mixture it was incubated at $37^{\circ} \mathrm{C}$. The absorbance was read after $30 \mathrm{~min}$ at $517 \mathrm{~nm}$. DPPH radical scavenging activity was expressed as $\mu \mathrm{mol}$ of Trolox equivalent per $\mathrm{g}$ of purified dry extract ( $\mu \mathrm{mol} \mathrm{TE} / \mathrm{g} \mathrm{PDE})$.

\section{Identification of phenolic compounds by HPLC-DAD}

HPLC analysis of gallic acid, caffeic acid, rutin, chlorogenic acid, quercetin, apigenin and kaempferol were performed according to the procedure described by Seal ${ }^{18}$, with some modifications. Briefly, a VWR HITACHI Chromaster 600 HPLC with a diode array detector (HPLCDAD 300), autosampler and a reversed phase C18 column $(5 \mu \mathrm{m}$ particle size, i.d. $4.6 \times 250 \mathrm{~mm}$ ) was used. The mobile phase consisted of $1 \%$ acetic acid (A) and $100 \%$ acetonitrile solution (B). The gradient profile was from 10 to $90 \% \mathrm{~B}$ from 0 to the desired gradient time $(28,39$ and $50 \mathrm{~min}$ ) at a flow rate of $0.7 \mathrm{~mL} / \mathrm{min}$. Detection was performed at 272 and $414 \mathrm{~nm}$ using a photodiode array detector.

\section{a-amylase inhibitory assay}

In vitro inhibitory activity on $\alpha$-amylase was evaluated according to a previous study ${ }^{19}$, with minor modifications. Briefly, a volume of 50 $\mu \mathrm{L}$ of each extract was mixed with $50 \mu$ of the $\alpha$-amylase pancreatic enzyme solution, previously dissolved in $0.1 \mathrm{M}$ phosphate buffered saline ( $\mathrm{pH} 6.9)$ at a concentration of $5 \mathrm{U} / \mathrm{ml}$. The mixture was incubated at $37^{\circ} \mathrm{C}$ for $60 \mathrm{~min}$, then $50 \mu \mathrm{L}$ of a starch solution $(0.5 \% \mathrm{w} / \mathrm{v})$ dissolved in $0.1 \mathrm{M}$ phosphate buffered saline was added, and incubated at $37^{\circ} \mathrm{C}$ for $5 \mathrm{~min}$. Then, $50 \mu \mathrm{L}$ of Dinitrosalicylic acid (DNS) was added, at a concentration of $96 \mathrm{mM}$, followed by incubation in water at $100{ }^{\circ} \mathrm{C}$ for $5 \mathrm{~min}$, allowing cooling for $5 \mathrm{~min}$ at room temperature. The absorbance was read at $540 \mathrm{~nm}$ in an ELISA reader (Spectra max 190, Molecular Devices). All the samples were processed in triplicate. The absorbance of the final extract was obtained by subtracting the blank reading from the corresponding sample. The percentage of $\alpha$-amylase inhibition was calculated using Eq. (1) below:

$\%$ inhibition $=\frac{\triangle A 540 \text { control }-\triangle A 540 \text { extract }}{\Delta A 540 \text { extract }} \times 100$ 


\section{a-glucosidase inhibitory assay}

In vitro activity on $\alpha$-glucosidase was carried out according to the method described previously ${ }^{19}$, with some modifications. Briefly, to each $50 \mu \mathrm{l}$ of each extract was added $50 \mu \mathrm{l}$ of $0.1 \mathrm{M}$ potassium phosphate buffer ( $\mathrm{pH}$ 6.9) and $100 \mu \mathrm{l}$ of $0.1 \mathrm{M}$ potassium phosphate buffer $(\mathrm{pH}$ 6.9) containing $\alpha$-glucosidase solution $(0.5 \mathrm{U} / \mathrm{ml})$ of Saccharomyces cerevisiae, the mixture was incubated at $37^{\circ} \mathrm{C}$ for $30 \mathrm{~min}$. Then, $50 \mu \mathrm{l}$ of $5 \mathrm{mM}$ solution of $p$-nitrophenyl-D- $\alpha$-glucopyranoside (PNPG) in 0.1 $\mathrm{M}$ potassium phosphate buffer ( $\mathrm{pH}$ 6.9) was added, and the mixture was incubated at $37^{\circ} \mathrm{C}$ for $5 \mathrm{~min}$. To stop the reaction, $50 \mu \mathrm{l}$ of sodium carbonate $\left(\mathrm{Na}_{2} \mathrm{CO}_{3}\right)$ was added and incubated for $5 \mathrm{~min}$. The absorbance was read at $405 \mathrm{~nm}$ in an ELISA reader (Spectra max 190, Molecular Devices). Before and after incubation, the change in absorbance of the sample $\left(\mathrm{A}_{405}\right.$ extract $)$ and control $\left(\mathrm{A}_{405}\right.$ control) containing $50 \mu \mathrm{L}$ of buffer solution instead of the extract was recorded in an ELISA reader (Spectra max 190, Molecular Devices). All the samples were processed in triplicate. The percentage of $\alpha$-glucosidase inhibition was calculated using Eq. (2) below:

$\%$ inhibition $=\frac{\Delta A 405 \text { control }-\triangle A 405 \text { extract }}{\Delta A 405 \text { extract }} \times 100$

\section{Calculation of $\mathrm{IC}_{50}$}

To calculate $\mathrm{IC}_{50}$ values, $\log _{10}$ of inhibitor concentrations were plotted against percent inhibition for each enzyme assay evaluated. In the $\alpha$-amylase and $\alpha$-glucosidase inhibition assays, concentrations of the quinoa and cañihua extracts between 50 and $500 \mu \mathrm{g} / \mathrm{mL}$ were evaluated. The $\mathrm{IC}_{50}$ corresponded to the concentration required to obtain $50 \%$ inhibition of enzyme activity.

\section{Statistical analysis}

All the assays were performed in triplicate. The results were expressed as mean \pm standard deviation, and analyzed using SPSS for Windows version 24.0 (SPSS, Inc., Chicago, IL, USA). The means were compared by one-way ANOVA followed by Tukey's post hoc test $(\mathrm{p}<0.05)$. Statistical correlation among different variables was carried out using the Pearson coefficient $(r)$ and the results were statistically significant when $\mathrm{p}<0.05$.

\section{RESULTS}

\section{Total phenolic and flavonoid content and DPPH radical scavenging activity}

As shown in Table 1, the total phenolic and flavonoid content, and DPPH radical scavenging activity was significantly different between the quinoa and cañihua varieties $(\mathrm{p}<0.05)$. In quinoa varieties $(\mathrm{QNC}$ and QSI), total phenolic and flavonoid content, and DPPH radical scavenging activity was ranged from 1.98 to $2.34 \mathrm{mg}$ GAE/g PDE, 1.40 to $1.96 \mathrm{mg} \mathrm{CE} / \mathrm{g} \mathrm{PDE}$ and 0.21 to $0.87 \mu \mathrm{mol} \mathrm{TE} / \mathrm{g} \mathrm{PDE}$, respectively; while in the cañihua varieties (CII and CCC), total phenolic and flavonoid content, and DPPH radical scavenging activity ranged from 2.99 to $3.37 \mathrm{mg} \mathrm{GAE} / \mathrm{g}$ PDE, 2.20 to $2.95 \mathrm{mg} \mathrm{CE} / \mathrm{g} \mathrm{PDE}$ and 1.98 to $2.20 \mu \mathrm{mol} \mathrm{TE} / \mathrm{g}$ PDE, respectively. The cañihua varieties (CII and CCC) presented significantly higher levels of total phenolics, total flavonoids and DPPH radical scavenging activity compared to the quinoa varieties (QNC and QSI) ( $\mathrm{p}<0.05)$; being the CII, the Andean grain that showed significantly higher levels of total phenolics, total flavonoids and DPPH radical scavenging activity $(3.33 \pm 0.05 \mathrm{mg} \mathrm{GAE} / \mathrm{g}$ PDE, $2.87 \pm 0.07 \mathrm{mg}$ $\mathrm{CE} / \mathrm{g} \mathrm{PDE}$ and $2.07 \pm 0.06 \mu \mathrm{mol} \mathrm{TE} / \mathrm{g} \mathrm{PDE}$, respectively) with respect to the remaining samples evaluated $(\mathrm{p}<0.05)$.

\section{Identification of phenolic compounds by HPLC-DAD}

In the quinoa and cañihua varieties, the HPLC-DAD analysis of the levels of gallic acid, caffeic acid, rutin, chlorogenic acid, quercetin, apigenin and kaempferol was obtained (data not shown), showing detectable values for gallic acid, rutin and chlorogenic acid. As shown in Table 2, the cañihua varieties (CII and CCC) presented a significantly higher content of chlorogenic acid compared to the quinoa varieties

Table 1: Total phenolics and flavonoids, and DPPH radical scavenging activity in two varieties of quinoa and two varieties of cañihua from the Andean Region of Peru.

\begin{tabular}{cccc}
\hline & $\begin{array}{c}\text { Total phenolics } \\
(\mathrm{mg} \mathrm{GAE} / \mathrm{g} \text { PDE })\end{array}$ & $\begin{array}{c}\text { Total flavonoids } \\
(\mathrm{mg} \text { CE/g PDE) }\end{array}$ & $\begin{array}{c}\text { DPPH radical } \\
\text { scavenging activity } \\
(\mu \mathrm{mol} \text { TE/g PDE) }\end{array}$ \\
\hline CII & $3.33 \pm 0.05^{\mathrm{a}}$ & $2.87 \pm 0.07^{\mathrm{a}}$ & $2.07 \pm 0.06^{\mathrm{a}}$ \\
CCC & $3.02 \pm 0.03^{\mathrm{b}}$ & $2.38 \pm 0.29^{\mathrm{b}}$ & $2.06 \pm 0.13^{\mathrm{a}}$ \\
QNC & $2.32 \pm 0.02^{\mathrm{c}}$ & $1.86 \pm 0.10^{\mathrm{c}}$ & $0.84 \pm 0.03^{\mathrm{b}}$ \\
QSI & $2.03 \pm 0.05^{\mathrm{d}}$ & $1.49 \pm 0.08^{\mathrm{c}}$ & $0.22 \pm 0.01^{\mathrm{c}}$ \\
\hline
\end{tabular}

CII: Cañihua “INIA 406-ILLPA”, CCC: Cañihua “Cupi”, QNC: Quinoa “Negra Collana”, QSI: Quinoa "Salcedo INIA", GAE: Gallic acid equivalent, CE: Catechin equivalent, TE: Trolox equivalent, PDE: Purified dry extract. Values (mean $\pm \mathrm{SD}, n=3$ ) in the same column with different letters (a-d) are significantly different (One-way ANOVA with Tukey's multiple comparison test, $\mathrm{p}<0.05$ ).

Table 2: Phenolic compounds measured by HPLC-DAD in two varieties of quinoa and two varieties of cañihua from the Andean Region of Peru.

\begin{tabular}{cccc|}
\hline & Gallic acid & Rutin & Chlorogenic acid \\
\hline & & $(\mathrm{mg} / 100 \mathrm{~g}$ flour $)$ & \\
\hline CII & $7.78 \pm 0.09^{\mathrm{a}}$ & $33.15 \pm 0.05^{\mathrm{b}}$ & $75.67 \pm 0.02^{\mathrm{a}}$ \\
CCC & $5.23 \pm 0.07^{\mathrm{b}}$ & $32.78 \pm 0.04^{\mathrm{c}}$ & $71.53 \pm 0.03^{\mathrm{b}}$ \\
QNC & $4.8 \pm 0.05^{\mathrm{c}}$ & $29.18 \pm 0.04^{\mathrm{d}}$ & $18.48 \pm 0.04^{\mathrm{c}}$ \\
QSI & $4.51 \pm 0.07^{\mathrm{c}}$ & $33.89 \pm 0.03^{\mathrm{a}}$ & $14.21 \pm 0.03^{\mathrm{d}}$ \\
\hline
\end{tabular}

CII: Cañihua "INIA 406-ILLPA", CCC: Cañihua "Cupi", QNC: Quinoa "Negra Collana”, QSI: Quinoa "Salcedo INIA". Values (mean $\pm S D, n=3$ ) in the same column with different letters $(a-d)$ are significantly different (One-way ANOVA with Tukey's multiple comparison test, $\mathrm{p}<0.05$ ). 
Table 3: In vitro a-amylase and a-glucosidase inhibitory activities in two varieties of quinoa and two varieties of cañihua from the Andean Region of Peru.

\begin{tabular}{ccc|} 
& $\begin{array}{c}\text { a-Amylase } \\
I C_{50}(\mathrm{mg} / \mathrm{mL})\end{array}$ & $\begin{array}{c}\text { a-Glucosidase } \\
\mathrm{IC}_{50}(\mathrm{mg} / \mathrm{mL})\end{array}$ \\
\hline CII & $31.66 \pm 2.19^{\mathrm{a}}$ & $9.34 \pm 0.83^{\mathrm{a}}$ \\
CCC & $9.43 \pm 0.57^{\mathrm{b}}$ & $8.89 \pm 0.38^{\mathrm{a}}$ \\
QNC & $11.18 \pm 1.32^{\mathrm{b}}$ & $9.44 \pm 0.12^{\mathrm{a}}$ \\
QSI & $8.30 \pm 0.27^{\mathrm{b}}$ & $9.85 \pm 1.76^{\mathrm{a}}$
\end{tabular}

CII: Cañihua "INIA 406-ILLPA", CCC: Cañihua "Cupi", QNC: Quinoa "Negra Collana", QSI: Quinoa "Salcedo INIA". Values (mean \pm SD, $n=3$ ) in the same row with different letters $(a-b)$ are significantly different (One-way ANOVA with Tukey's multiple comparison test, $\mathrm{p}<0.05$ ).

$(\mathrm{p}<0.05)$, being $\mathrm{CII}$, the Andean grain that presented the highest levels $(75.67 \mathrm{mg} / 100 \mathrm{~g}$ flour$)$ of this phenolic compound compared the remaining grains evaluated $(\mathrm{p}<0.05)$. Regarding the levels of gallic acid and rutin, no significant differences were observed between the varieties of quinoa and cañihua. Gallic acid levels were ranged from 4.43 to $7.86 \mathrm{mg} / 100 \mathrm{~g}$ flour, while rutin levels varied between 29.14 to $33.91 \mathrm{mg} / 100 \mathrm{~g}$ flour.

\section{a-amylase and a-glucosidase inhibitory activity}

As shown in Table 3, the inhibitory activity on the $\alpha$-amylase and a-glucosidase enzymes was evaluated using $\mathrm{IC}_{50}$ values. In the quinoa varieties, the inhibitory activity on the $\alpha$-amylase and $\alpha$-glucosidase ranged from 7.99 to 12.01 and 8.07 to $11.58 \mu \mathrm{g} / \mathrm{mL}$, while in the cañihua varieties; the inhibitory activity on the $\alpha$-amylase and $\alpha$-glucosidase varied between 9.02 to 34.05 and 8.47 to $10.22 \mu \mathrm{g} / \mathrm{mL}$, respectively. CCC, QNC, and QSI showed a significant greater inhibition on the enzyme $a$-amylase with respect to CII $(p<0.05)$. Regarding the inhibition on the $a$-amylase enzyme, no significant differences were observed between the Andean grains studied. Furthermore, in the varieties of quinoa and cañihua, a significant correlation was observed between the $\mathrm{IC}_{50}$ for $\alpha$-amylase with the levels of total phenolics, total flavonoids, DPPH radical scavenging activity, gallic acid and chlorogenic acid $(r=0.840$, $r=0.822, r=0.885$ and $r=0.875$; respectively, $\mathrm{p}<0.05$ ). In the varieties of cañihua, the $\mathrm{IC}_{50}$ for $\alpha$-amylase was significantly correlated with the content of total polyphenols, total flavonoids, gallic acid, rutin and chlorogenic acid $(r=0.798, r=0.892, r=0.687, r=0.966$ and $r=0.693$; respectively, $\mathrm{p}<0.01)$. Conversely, in the varieties of quinoa and cañihua, a poor correlation was observed between the $\mathrm{IC}_{50}$ for $\alpha$-amylase with the other variables evaluated in this study.

\section{DISCUSSION}

Regarding the total content of phenolics and flavonoids in Andean grains, a previous study in 11 varieties of cañihua and 15 varieties of quinoa from the Puno Region, Peru, reported that the levels of total phenolics in the varieties of quinoa and cañihua were ranged from 0.35 to $1.40 \mathrm{mg} \mathrm{GAE} / \mathrm{g}$ extract and 0.67 to $0.85 \mathrm{mg} \mathrm{GAE} / \mathrm{g}$ extract, respectively ${ }^{5}$, while in the "Cupi" variety of cañihua from the Peruvian Antiplane, the total phenolic content was $2.5 \mathrm{mg}$ GAE/g extract. ${ }^{20}$ Another study reported that the total flavonoid content for the white grain of ground quinoa from India presented levels of $1.09 \pm 0.04 \mathrm{mg}$ $\mathrm{GAE} / \mathrm{g}$ extract. These values were lower than those reported in our study, possibly due to the differences in the extraction method of phenolic compounds. Studies carried out by Valencia et al. ${ }^{21}$ in 24 accessions of quinoa from the national collection of the National Institute of Agricultural Innovation (INIA) of Peru, showed that the total phenolic content was ranged from 0.78 to $3.34 \mathrm{mg} \mathrm{GAE} / \mathrm{g}$ extract, while the total flavonoid content ranged from 0.12 to $1.03 \mathrm{mg} \mathrm{CE} / \mathrm{g}$ extract. Another study in 13 Peruvian Altiplano colored quinoa seeds reported that total phenolic levels ranged 1.23 to $3.24 \mathrm{mg}$ GAE/g extract. ${ }^{22}$ Regarding the total phenolic content, our values were similar to those reported by Valencia et al. ${ }^{21}$ and Abderrahim et al. ${ }^{22}$, while our total flavonoid levels were approximately 1.8 times higher than in a previous study. ${ }^{21}$

Concerning in vitro antioxidant activity evaluated by the DPPH radical scavenging test, in 11 varieties of cañihua and 15 varieties of quinoa from the Puno Region, Peru, it was found that the in vitro antioxidant activity in the varieties of cañihua and quinoa varied between 0.47 to $9.58 \mu \mathrm{mol} \mathrm{TE} / \mathrm{g}$ extract and 0.37 to $5.44 \mu \mathrm{mol} \mathrm{TE} / \mathrm{g}$ of extract, respectively. ${ }^{5}$ Previous studies on accessions of colored quinoa from Peru also found that in vitro antioxidant activity ranged from 4.86 to $11.96 \mathrm{mmol} \mathrm{TE} / \mathrm{g}$ extract ${ }^{21}$ and 119.8 to $335.9 \mathrm{mmol} \mathrm{TE} / \mathrm{g}$ extract. ${ }^{22}$ These values were higher than those found in our study, possibly due to differences in the purification methods of phenolic compounds used. In the cañihua varieties (CII and CCC) evaluated in the present study, a poor correlation was found between DPPH radical scavenging activity with total phenolic and flavonoids levels. However, in the quinoa varieties (QNC and QSI), DPPH radical scavenging activity showed a significant correlation with the total phenolic and flavonoid content $(r$ $=0.973$ and $r=0.906$, respectively, $\mathrm{p}<0.05$ ).

Previous studies showed the inhibitory activity on the a-glucosidase and $\alpha$-amylase enzymes in quinoa (Chenopodium quinoa Willd) and cañihua (Chenopodium pallidicaule Aellen). At $5 \mathrm{mg}$ of sample weight, the inhibitory activity on a-glucosidase in red quinoa and cañihua was $30 \%$ and $15 \%$, respectively. When evaluating the inhibitory activity on a-amylase, no inhibitory activity of this enzyme was detected in any of the grains evaluated. ${ }^{19}$ Another study, in whole grain quinoa and its milled fractions, evaluated the composition of phenolic compounds and their inhibitory effects on the activity of $\alpha$-glucosidase and $\alpha$-amylase enzymes. In the bran fractions compared to whole grain, a high and low inhibitory activity on $\alpha$-glucosidase and $\alpha$-amylase was observed. A high content of ferulic acid, rutin and quercetin was found in the bran fraction that presented a high inhibitory activity on a-glucosidase. ${ }^{14}$ In our study, the inhibitory activity on the $\alpha$-glucosidase and $\alpha$-amylase enzymes evaluated through the $\mathrm{IC}_{50}$ value, found a differential inhibition on the carbohydrate hydrolyzing enzymes associated with type 2 diabetes. Phenolic compounds such as caffeic acid and chlorogenic acid have been reported to inhibit carbohydrate hydrolyzing enzymes associated with type 2 diabetes ( $\alpha$-glucosidase and $\alpha$-amylase), in a dose-dependent manner, and may also lead to a reduction in sugars in the gastrointestinal tract. ${ }^{23}$ Likewise, other compounds such as gallic acid and rutin have also shown inhibitory effects against $\alpha$-glucosidase and $\alpha$-amylase enzymes. ${ }^{24,25}$ In our study, in the varieties of quinoa and cañihua, the inhibitory activity on $\alpha$-amylase was significantly correlated with the levels of gallic acid and chlorogenic acid. A kinetic study by Kalita et al. ${ }^{26}$ showed that a methanol extract from potato, which contained phenolic compounds such as chlorogenic acid, could act as a mixed inhibitor against carbohydrate hydrolyzing enzymes of type 2 diabetes such as $\alpha$-amylase and $\alpha$-glucosidase. Another study carried out with an anthocyanin-rich extract from sour cherries, which contained malvidin-3,5-O-diglycoside, showed a competitive inhibition on the enzyme $\alpha$-amylase. ${ }^{27}$ According to our findings, a poor correlation was observed between the inhibitory activity on $a$-amylase with the phenolic compounds measured by HPLC-DAD. These results suggest that other phenolic compounds could be involved in the inhibition of this enzyme. A study carried out with a methanolic extract of finger millet that contained phenolic compounds such as gallic acid, caffeic acid, ferulic acid and $p$-coumaric acid, showed a noncompetitive inhibition on the enzyme $\alpha$-glucosidase. ${ }^{28}$ Another study in which phenolic compounds such as genistein, tangeretin, pelargonidin, formononetin and delphinidin chloride were evaluated, exhibited $\mathrm{IC}_{50}$ values for glucosidase in the range of 165.51-506.20 nM, showing a non-competitive inhibition on this enzyme. ${ }^{29}$ 


\section{CONCLUSION}

In the varieties of quinoa (Chenopodium quinoa Willd.) and cañihua (Chenopodium pallidicaule Aellen) evaluated in the present study, our findings showed that the in vitro hypoglycemic activity of carbohydrate hydrolyzing enzymes associated with type 2 diabetes is related to the content of phenolic compounds and DPPH radical scavenging activity. The presence of gallic acid, rutin and chlorogenic acid was associated with an inhibition on the activity of the enzyme $\alpha$-amylase.

\section{ACKNOWLEDGEMENT}

This study was funded by a grant from the National Fund for Scientific, Technological Development and Technological Innovation (FONDECYT) of the National Council of Science, Technology and Technological Innovation (CONCYTEC) of Peru, Contract $\mathrm{N}^{\circ}$ 171-2015-FONDECYT.

\section{REFERENCES}

1. Repo-Carrasco-Valencia R, Hellström JK, Pihlava J-M, Mattila PH. Flavonoids and other phenolic compounds in Andean indigenous grains: Quinoa (Chenopodium quinoa), kañiwa (Chenopodium pallidicaule) and kiwicha (Amaranthus caudatus). Food Chem. 2010;120(1):128-33.

2. Vilcacundo R, Hernández-Ledesma B. Nutritional and biological value of quinoa (Chenopodium quinoa Willd.). Curr Opin Food Sci. 2017;14:1-6.

3. Pereira E, Cadavez V, Barros L, Encina-Zelada C, Stojković D, Sokovic $\mathrm{M}$, et al. Chenopodium quinoa Willd. (quinoa) grains: A good source of phenolic compounds. Food Res Int Ott Ont. 2020;137:109574.

4. Repo-Carrasco R, Espinoza C, Jacobsen S-E. Nutritional Value and Use of the Andean Crops Quinoa (Chenopodium quinoa) and Kañiwa (Chenopodium pallidicaule). Food Rev Int. 2003;19(1-2):179-89.

5. Repo de Carrasco R, Encina Zelada CR. Determinación de la capacidad antioxidante y compuestos fenólicos de cereales andinos: quinua (Chenopodium quinoa), kañiwa (Chenopodium pallidicaule) y kiwicha (Amaranthus caudatus). Rev Soc Quím Perú. 2008;74(2):85-99.

6. Gothai S, Ganesan P, Park S-Y, Fakurazi S, Choi D-K, Arulselvan P. Natural Phyto-Bioactive Compounds for the Treatment of Type 2 Diabetes: Inflammation as a Target. Nutrients. 2016;8(8)

7. Vargas-Uricoechea H, Casas-Figueroa LÁ. An Epidemiologic Analysis of Diabetes in Colombia. Ann Glob Health. 2015;81(6):742-53.

8. Dirección General de Epidemiología. Boletín Epidemiológico del Perú 27 SE 36. 2018 [Internet]. Lima, Peru; 2018 [cited 2021 Jan 25].

9. Carrillo-Larco RM, Bernabé-Ortiz A. [Type 2 diabetes mellitus in peru: a systematic review of prevalence and incidence in the general population]. Rev Peru Med Exp Salud Publica. 2019;36(1):26-36. doi: 10.17843/rpmesp.2019.361.4027.

10. Alkhatib A, Tsang C, Tiss A, Bahorun T, Arefanian H, Barake R, et al. Functional Foods and Lifestyle Approaches for Diabetes Prevention and Management. Nutrients. 20;9(12):1310.

11. Apaza V, Cáceres G, Estrada R, Pinedo R. Catalogue of Commercial Varieties of Quinoa in Peru: A future planted thousands of years a ago [Internet]. Rome, Italy: FAO; 2015 [cited 2021 Jan 25]. 86 p. Disponible en: http://www.fao.org/documents/card/en/c/f351e07bbd68-4724-a849-778dd44e6358/

12. Puno IEEAI-. INIA 406 - IIIpa: Nueva variedad de cañihua. Instituto Nacional de Innovación Agraria [Internet]. 2004 October [cited 2021 Jan 25].

13. Ligarda Samanez CA, Repo-Carrasco R, Encina Zelada CR, Herrera Bernabé I, Quinde-Axtell Z. Extracción con soluciones neutra y alcalina para el aislamiento de fibra soluble e insoluble a partir de salvado de quinua (Chenopodium quinoa Willd.), kiwicha (Amaranthus caudatus L.) y cañihua (Chenopodium pallidicaule Aellen.). Rev Soc Quím Perú. 2012;78(1):53-64.

14. Hemalatha P, Bomzan DP, Sathyendra Rao BV, Sreerama YN Distribution of phenolic antioxidants in whole and milled fractions of quinoa and their inhibitory effects on $\alpha$-amylase and $\alpha$-glucosidase activities. Food Chem. 2016;199:330-8.

15. Herrera-Calderon O, Enciso-Roca E, Pari-Olarte B, Arroyo-Acevedo J. Phytochemical screening, antioxidant activity and analgesic effect of Waltheria ovata Cav. roots in mice. Asian Pac J Trop Dis. 2016;6(12):1000-3.

16. Wolfe K, Wu X, Liu RH. Antioxidant activity of apple peels. J Agric Food Chem. 2003;51(3):609-14.

17. Brand-Williams W, Cuvelier ME, Berset C. Use of a free radical method to evaluate antioxidant activity. LWT - Food Sci Technol. 1995;28(1):25-30.

18. Seal T. Quantitative HPLC analysis of phenolic acids, flavonoids and ascorbic acid in four different solvent extracts of two wild edible leaves, Sonchus arvensis and Oenanthe linearis of North-Eastern region in India. J Appl Pharm Sci. 2016;157-66.

19. Ranilla LG, Apostolidis E, Genovese MI, Lajolo FM, Shetty K. Evaluation of indigenous grains from the Peruvian Andean region for antidiabetes and antihypertension potential using in vitro methods. J Med Food. 2009;12(4):704-13.

20. Abderrahim F, Huanatico E, Repo-Carrasco-Valencia R, Arribas SM, Gonzalez MC, Condezo-Hoyos L. Effect of germination on total phenolic compounds, total antioxidant capacity, Maillard reaction products and oxidative stress markers in canihua (Chenopodium pallidicaule). J Cereal Sci. 2012;56(2):410-7.

21. Valencia Z, Cámara F, Ccapa K, Catacora P, Quispe F. Compuestos bioactivos y actividad antioxidante de semillas de quinua peruana (Chenopodium quinoaW.). Rev Soc Quím Perú. 2017;83(1):16-29.

22. Abderrahim F, Huanatico E, Segura R, Arribas S, Gonzalez MC, Condezo-Hoyos L. Physical features, phenolic compounds, betalains and total antioxidant capacity of coloured quinoa seeds (Chenopodium quinoa Willd.) from Peruvian Altiplano. Food Chem. 2015;183:83-90.

23. Oboh G, Agunloye OM, Adefegha SA, Akinyemi AJ, Ademiluyi $A O$. Caffeic and chlorogenic acids inhibit key enzymes linked to type 2 diabetes (in vitro): a comparative study. J Basic Clin Physiol Pharmacol. 2015;26(2):165-70.

24. Oboh G, Ogunsuyi OB, Ogunbadejo MD, Adefegha SA. Influence of gallic acid on $\alpha$-amylase and $\alpha$-glucosidase inhibitory properties of acarbose. J Food Drug Anal. 2016;24(3):627-34.

25. Riyaphan J, Jhong C-H, Lin S-R, Chang C-H, Tsai M-J, Lee D-N, et al. Hypoglycemic Efficacy of Docking Selected Natural Compounds against $\alpha$-Glucosidase and $\alpha$-Amylase. Mol Basel Switz. 2018;23(9).

26. Kalita D, Holm DG, LaBarbera DV, Petrash JM, Jayanty SS. Inhibition of $\alpha$-glucosidase, $\alpha$-amylase, and aldose reductase by potato polyphenolic compounds. PLoS ONE. 2018;13(1):e0191025.

27. Homoki JR, Nemes A, Fazekas E, Gyémánt G, Balogh P, Gál F, et al. Anthocyanin composition, antioxidant efficiency, and $\alpha$-amylase inhibitor activity of different Hungarian sour cherry varieties (Prunus cerasus L.). Food Chem. 2016;194:222-9.

28. Shobana S, Sreerama YN, Malleshi NG. Composition and enzyme inhibitory properties of finger millet (Eleusine coracana L.) seed coat phenolics: Mode of inhibition of $\alpha$-glucosidase and pancreatic amylase. Food Chem. 2009;115(4):1268-73.

29. Demir Y, Durmaz L, Taslimi P, Gulçin İ. Antidiabetic properties of dietary phenolic compounds: Inhibition effects on $\alpha$-amylase, aldose reductase, and $\alpha$-glycosidase. Biotechnol Appl Biochem. 2019;66(5):781-6. 


\section{GRAPHICAL ABSTRACT}
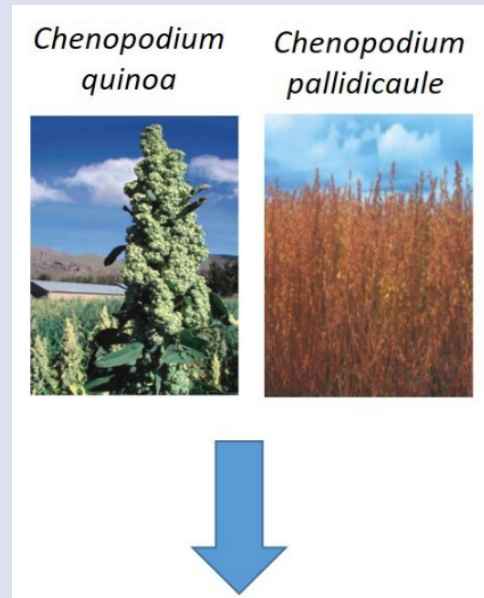

$80 \%$ ethanol extraction
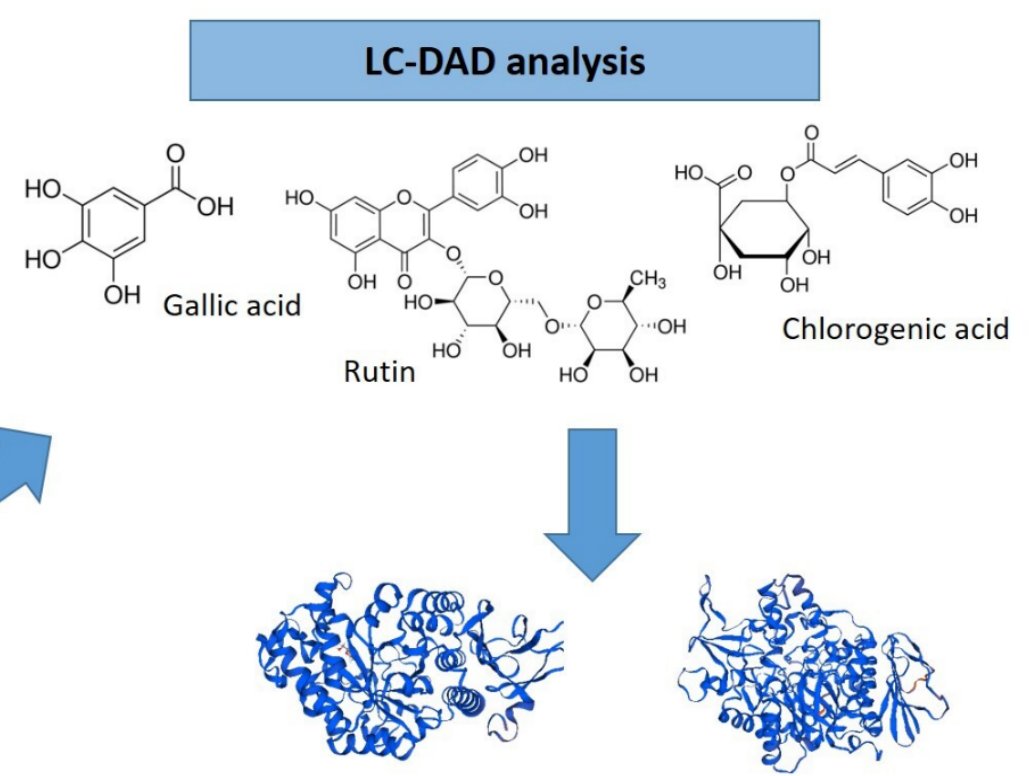

\section{In vitro $\alpha$-amylase and $\alpha$-glucosidase inhibitory activity assay}

\section{ABOUT AUTHORS}

- Jorge Coronado-Olano, MS.c. in Food Technology from the Universidad Nacional Agraria La Molina, Lima, Peru. Food Industries Engineer with more than 10 years of experience in the areas of research and development, production, supervision, monitoring and food safety. Research interests: Functional foods and Nutraceuticals, Andean grains.

- Ritva Repo-Carrasco-Valencia has a PhD. degree in Food Chemistry from University of Turku, Finland and MSc. degree in Cereal Chemistry and Technology, University of Helsinki, Finland. She is currently a professor and research scientist at the Universidad Nacional Agraria La Molina, Lima, Peru. She is director of the Centre of Innovation for Andean Grains.

- Oscar Reátegui, MS.c., Researcher at the Universidad Científica del Sur, Lima, Peru. Research interests: Natural Product Chemistry, Functional and nutraceutical foods.

- Emily Toscano-Guerra, Ph.D. student in Biochemistry and Molecular Biology at the Autonomous University of Barcelona, Spain. She worked for 4 years as a research assistant at the Universidad Peruana Cayetano Heredia, Peru. She currently works as a pre-doctoral researcher in the Laboratory of Cell Signaling and Cancer Progression of the Clinical Biochemistry Group of the Vall 'Hebron Research Institute (VHIR), Barcelona, Spain.

- Mirko Zimic, Ph.D., Principal Professor at the Universidad Cayetano Heredia, Lima, Peru. Senior researcher in the applications of immunoinformatics on nutrition and health.

- Elisa Valdez, Researcher at the Universidad Nacional Federico Villareal, Lima, Peru.

- Ivan Best, Ph.D., Professor of Biochemistry at the Universidad San Ignacio de Loyola, Lima, Peru. Senior researcher with more than 20 years of experience in the execution of $R+D+I$ projects, publication of scientific articles and speaker at international conferences. He is currently coordinator of the group Food Science, Technology and Innovation at the Universidad San Ignacio de Loyola. Research interests: Functional foods and Nutraceuticals, Andean grains, Immunology and Nutrition.

Cite this article: Coronado-Olano J, Repo-Carrasco-Valencia R, Reategui O, Toscano E, Valdez E, Zimic M, et al. Inhibitory Activity Against $\alpha$-amylase and $\alpha$-glucosidase by Phenolic Compounds of quinoa (Chenopodium quinoa Willd.) and Cañihua (Chenopodium pallidicaule Aellen) from the Andean Region of Peru. Pharmacog J. 2021;13(4): 896-901. 